\title{
Nitrogen utilization during germination of somatic embryos of Norway spruce: revealing the importance of supplied glutamine for nitrogen metabolism
}

\author{
Johanna Carlsson $^{1,2} \cdot$ Ulrika Egertsdotter $^{1,3} \cdot$ Ulrika Ganeteg $^{1} \cdot$ Henrik Svennerstam $^{4}(\mathbb{D}$
}

Received: 17 May 2018 / Accepted: 27 October 2018 / Published online: 9 November 2018

(c) The Author(s) 2018

\begin{abstract}
Key message This paper shows that germinating Norway spruce somatic embryos are dependent on the carbon and nitrogen supplied in the medium, and that supplied glutamine accounts for $50 \%$ of assimilated nitrogen during germination.

Abstract The female megagametophyte, which provides the zygotic embryo with nitrogen (N), carbon $(\mathrm{C})$ and energy during germination, is not present in Norway spruce (Picea abies) mature somatic embryos. Therefore, somatic embryos presumably rely on nutrients supplied in the germination medium in addition to their storage compounds accumulated during maturation. However, to what extent stored versus supplied compounds contribute to a somatic embryo germination is unclear. In this 24-day study, we addressed the above question by monitoring the biomass changes and the $\mathrm{N}$ and $\mathrm{C}$ budget during somatic embryo germination, under low-intensity red light. We found that the $\mathrm{C}$ and $\mathrm{N}$ storage reserves, accumulated during the maturation phase, were not sufficient to support the growth of the germinating somatic embryos, rather they were dependent on the medium components. In addition, in a previous study it has been found that glutamine (Gln) supplied in the medium was crucial for maintaining the primary amino acid (AA) metabolism and growth of the proliferating embryogenic cultures of Norway spruce (Carlsson et al., PLoS One 12(8):e0181785, 2017). Therefore, we hypothesised that Gln would be required as a significant source of $\mathrm{N}$ also during somatic embryo germination. By tracing the uptake of isotopically labelled $\mathrm{N}$-sources from the medium and further into primary $\mathrm{N}$ assimilation, we found that Gln was the preferred source of $\mathrm{N}$ for the germinating somatic embryos, accounting for $50 \%$ of assimilated N. As the amounts of both arginine (Arg) and Gln were increased in the germinating somatic embryos, it also suggested that germination in low-intensity red light promoted N storage, similar to what has been observed in the zygotic embryo maturation in conifers (King, Gifford, Plant Physiol 113:1125-1135, 1997).
\end{abstract}

Keywords Amino acids · Glutamine $\cdot$ Nitrogen assimilation $\cdot$ Somatic embryogenesis

\section{Introduction}

Communicated by Klimaszewska.

Electronic supplementary material The online version of this article (https://doi.org/10.1007/s00468-018-1784-y) contains supplementary material, which is available to authorized users.

Henrik Svennerstam

henrik.svennerstam@umu.se

1 Department of Forest Genetics and Plant Physiology, Umeå Plant Science Centre, Swedish University of Agricultural Sciences, 90183 Umeå, Sweden

2 Seed Production, Svenska Skogsplantor AB, 34151 Lagan, Sweden
Conifer somatic embryos are generated in a process in which plant growth regulators are used to induce somatic embryos from somatic cells (Elhiti et al. 2013; Pullman and Bucalo 2014; Winkelmann 2016). A major difference between

G.W. Woodruff School of Mechanical Engineering, Georgia Institute of Technology, 500 Tenth Street NW, Atlanta, GA 30332-0620, USA

4 Department of Plant Physiology, Umeå Plant Science Centre, Umeå University, 90736 Umeå, Sweden 
zygotic embryogenesis (ZE) and somatic embryogenesis (SE) is the absence of a megagametophyte in the latter. Consequently, somatic embryos rely on reserves accumulated during embryo maturation and/or media-supplied nutrients (Hakman 1993; Goldberg et al. 1994). The main objectives in this study were (1) to determine the relative contribution of nitrogen $(\mathrm{N})$ and carbon $(\mathrm{C})$ uptake versus the endogenous stocks (present at the end of maturation) to Norway spruce (Picea abies) somatic embryos during germination and (2) to follow the assimilation of $\mathrm{N}$ supplied in the medium.

In pine (Pinus ssp.) seeds, storage reserves are mainly contained within the megagametophyte (Stone and Gifford 1997; Trontin et al. 2016). Seed storage proteins have a high $\mathrm{N}$ content and are broken down to amino acids (AAs) (Lammer and Gifford 1989; King and Gifford 1997). Storage carbohydrates and lipids have a high $\mathrm{C}$ content and are transformed to soluble carbohydrates (Ching 1966; Carrier et al. 1997). AAs and soluble carbohydrates released from the storage proteins are used for the synthesis of metabolites, building biomass and provide energy during germination. $\mathrm{N}$ is a building block of several biomolecules involved in photosynthesis, e.g. chlorophyll and key enzymes in the Calvin cycle, and is thus vital for the assimilation of $\mathrm{C}$ into plant metabolism. Similarly, $\mathrm{C}$ is an integral part of $\mathrm{N}$ metabolism, serving as an energy source and providing C-backbones to $\mathrm{N}$ assimilation and AA biosynthesis (reviewed by Pratelli and Pilot 2014).

Several phases of the SE-process take place in darkness under heterotrophic conditions. Thus, SE tissue culture systems are dependent on exogenously added sugars for $\mathrm{C}$ and energy. Several different sugars are commonly used in plant culture media of which sucrose is the most widely used (Yaseen et al. 2012). In plants, sucrose can be hydrolysed by two different enzymes, invertase or sucrose synthase. Invertase and sucrose synthase hydrolyse sucrose into glucose and fructose, and into fructose and uridine diphosphate glucose, respectively. The products are metabolised further by enzymes in the glycolysis pathway, providing substrates for the citric acid cycle and for biosynthesis of, e.g. AAs and lipids (Huppe and Turpin 1994; Nunes-Nesi et al. 2010; Krasavina et al. 2014).

Incorporation of $\mathrm{N}$ into AAs is a prerequisite for synthesising proteins, nucleotides and other metabolites needed for plant development and growth (Nunes-Nesi et al. 2010). N is assimilated via two pathways, depending on which form of $\mathrm{N}$ acquired. Nitrate $\left(\mathrm{NO}_{3}{ }^{-}\right)$taken up from the growth substrate is reduced to ammonium $\left(\mathrm{NH}_{4}{ }^{+}\right)$by the enzymes nitrate reductase and nitrite reductase (Lam et al. 1996; Krapp 2015). $\mathrm{NH}_{4}^{+}$, acquired either by direct uptake, as an assimilation product of $\mathrm{NO}_{3}{ }^{-}$, or as a photorespiration product, is incorporated into Gln and glutamate (Glu) via the enzymatic pathway of glutamine synthetase/glutamate-2-oxoglutarate aminotransferase (GS/GOGAT) (Lea and Ireland
1999; Cánovas et al. 2007; Forde and Lea 2007). Sources of inorganic $\mathrm{N}\left(\mathrm{NH}_{4}{ }^{+}\right.$and $\left.\mathrm{NO}_{3}{ }^{-}\right)$and organic $\mathrm{N}$ (mainly AAs) are commonly provided in in vitro culture media in various mixtures (Bozhkov et al. 1993; George and de Klerk 2008; Pullman and Bucalo 2014). The reason for adding single or mixed AAs to the culture media is the positive impact of organic $\mathrm{N}$ on overall tissue culture performance (Kirby 1982; Pinto et al. 1993; Khlifi and Tremblay 1995; Ogita et al. 2001; Vasudevan et al. 2004; Hamasaki et al. 2005).

In the context of conifers, e.g. silver fir (Abies alba) (Hristoforoglu et al. 1995), white spruce (Picea glauca) (Barrett et al. 1997) and Norway spruce (Bozhkov et al. 1993), studies have shown that supplementing the culture medium with organic N, e.g. Gln or casein hydrolysate, enhances SE initiation frequency and proliferation growth, as compared with medium supplemented with solely inorganic $\mathrm{N}$. In a recent study, it has been shown that growing proliferating pro-embryogenic masses (PEMs) of Norway spruce on semi-solid medium with $\mathrm{NH}_{4}{ }^{+}$and $\mathrm{NO}_{3}{ }^{-}$in combination with Gln, had a positive effect on PEM culture growth as compared with the growth on solely inorganic N (Carlsson et al. 2017). The same study also showed that the amount of Gln-N taken up was higher than the relative amount supplied in the medium and that Gln-N was assimilated into AA metabolism to a higher extent than inorganic $\mathrm{N}$, contributing to more than half of the $\mathrm{N}$ in the total free AA (TFAA) pool of proliferating PEMs.

Many studies have investigated how the culture conditions during the maturation phase influence a somatic embryo's capability to germinate, including factors such as, osmoticum (Bozhkov and von Arnold 1998; Hazubska-Przybył and Wawrzyniak 2017), abscisic acid (Bozhkov and von Arnold 1998; Montalbán et al. 2010; Alvarez et al. 2013), redox agents (Stasolla et al. 2004; Pullman et al. 2015), gelling agents (Klimaszewska et al. 2000; Morel et al. 2014a; LeluWalter et al. 2018) and desiccation treatments (HazubskaPrzybył et al. 2015; Carneros et al. 2017). In terms of $\mathrm{N}$ metabolism, studies have suggested that a reduced accumulation of storage protein during maturation can have a negative impact on the quality of the mature somatic embryos, as compared with zygotic embryos (Klimaszewska et al. 2004, 2016; Morel et al. 2014b).

Increased rates of germination and survival after transfer from in vitro to ex vitro conditions are desirable for many plant applications. For Norway spruce SE, it would benefit the currently most acute bottleneck of SE, both in terms of knowledge and success as a commercial cost-effective complement to the existing plant propagation methods. The existing literature addressing $\mathrm{N}$ and $\mathrm{C}$ during conifer somatic embryo germination is mostly comprised of omics data (e.g. metabolomics, proteomics and transcriptomics) (Robinson et al. 2009; Canales et al. 2014; Dobrowolska et al. 2017; Klubicová et al. 2017). However, in a recent study, improved 
root growth of pine somatic embryos germinated on medium supplemented with solely organic $\mathrm{N}$ was reported (Llebrés et al. 2017). Nevertheless, fundamental information regarding quantitative data with regards to $\mathrm{N}$ and $\mathrm{C}$ metabolism is lacking and further information is required for a better understanding of the somatic germination process to facilitate improvements in yield for commercial applications.

The overall aim of the project was to expand our knowledge of the $\mathrm{C}$ and $\mathrm{N}$ budget during the Norway spruce SE germination phase, with focus on $\mathrm{N}$ uptake and assimilation. The main goals of this research project were (i) to investigate the utilization of $\mathrm{C}$ and $\mathrm{N}$ stored in the mature somatic embryo versus the utilization of $\mathrm{C}$ and $\mathrm{N}$ supplied in the medium and (ii) to characterise $\mathrm{N}$ metabolism during the early stage of germination, investigating the relative use of different $\mathrm{N}$ sources supplied in the germination medium. Given the importance of Gln for PEMs (Carlsson et al. 2017), we hypothesised that Gln supplied in the medium would be a major contributor of $\mathrm{N}$ during somatic embryo germination.

\section{Materials and methods}

\section{Embryogenic line and maturation of somatic embryos}

Mature Norway spruce somatic embryos originating from the embryogenic cell line 11:12:02 were used for germination. The cell line was initiated at SweTree Technologies, Sweden, in 2011. Embryogenic cultures were sub-cultured biweekly on a semi-solid $1 / 2$-LP medium supplemented with $9.0 \mu \mathrm{M}$ 2,4-dichlorophenoxyacetic acid, $4 \mu \mathrm{M}$ N6-benzyladenine, $3.1 \mathrm{mM}$ Gln and 1\% sucrose (w/v) (von Arnold and Eriksson 1981). To initiate maturation, the clumps of embryogenic cultures were transferred to DKM maturation medium lacking plant growth regulators for one week, followed by DKM medium supplemented with $29.0 \mu \mathrm{M}$ abscisic acid and $3.1 \mathrm{mM}$ Gln (Krogstrup 1986) and a modified synchronization DKM medium supplemented with $0.25 \mathrm{M}$ myo-inositol (Egertsdotter and Clapham 2011) for six and two weeks, respectively. Mature somatic embryos with four or more developed cotyledons were harvested from the cultures and placed in a $5 \mathrm{~cm}$ (diameter) Petri dish. For 3 weeks, desiccation treatment was carried out by placing the $5 \mathrm{~cm}$ Petri dish (without the lid) inside a $9 \mathrm{~cm}$ Petri dish, holding $1 \mathrm{ml}$ of sterile water, with the lid on and sealed with PARAFILM ${ }^{\circledR} M$ M (Bemis Company, Inc.). The mature somatic embryos used in the experiments were obtained from five separate maturation batches. Samples of the desiccated embryo batches were collected to check if they were similar in terms of dry biomass (DW), $\mathrm{C}$ and $\mathrm{N}$ concentrations or $\mathrm{C}$ and $\mathrm{N}$ contents $(\mathrm{n}=5$, and for each replicate 23 embryos were pooled). Statistical analysis showed that the DW, C and $\mathrm{N}$ content of the maturation batches were not significantly different (Table S1). However, the $\mathrm{C}$ and $\mathrm{N}$ concentrations of the day $1-6$ batches were significantly different from those of days $12-24$.

\section{Experimental design and sample collection}

After desiccation, 23 mature somatic embryos were placed in a $9 \mathrm{~cm}$ Petri dish with $25 \mathrm{~mL}$ germination medium (Table S2). The composition in terms on $\mathrm{N}$ supplied in the germination medium is specified in Table 1 . The Petri dishes were placed under $24 \mathrm{~h}$ of red light $\left(5 \mu \mathrm{mol} \mathrm{m}{ }^{-2} \mathrm{~s}^{-1}\right.$; Philips TLD Red $18 \mathrm{~W})$. The rationale for growing the germinants in low-intensity red light was: (1) to limit photosynthesis to a very low level, ensuring that $\mathrm{C}$ was mainly acquired from sucrose supplied in the medium and (2) to promote root development (Kvaalen and Appelgren 1999; Merkle et al. 2005)

The germination medium was divided into five separate aliquots. Four aliquots were separately supplied with one of the four ${ }^{15} \mathrm{~N}$ isotopically labelled compounds, ${ }^{15} \mathrm{NH}_{4} \mathrm{NO}_{3}$ $\left(\geq 98 \%{ }^{15} \mathrm{~N}\right), \mathrm{NH}_{4}{ }^{15} \mathrm{NO}_{3}\left(\geq 98 \%{ }^{15} \mathrm{~N}\right),{ }^{15}$ amide-Gln $(\geq 98 \%$ $\left.{ }^{15} \mathrm{~N}\right)$ and ${ }^{15}$ amine-Gln $\left(\geq 98 \%{ }^{15} \mathrm{~N}\right)$. Gln amine and amide $\mathrm{N}$ were separately labelled, making it possible to evaluate if amine and amide $\mathrm{N}$ were utilized differently. The amount of ${ }^{15} \mathrm{~N}$-labelled compound added to the medium represented $22 \%$ of $\mathrm{NO}_{3}{ }^{-} \mathrm{N}$ (hence, a multiplication factor of 4.5 was used in the targeted AA data analysis calculations) and $100 \%$ of $\mathrm{NH}_{4}{ }^{+}-\mathrm{N}$, amine-Gln-N and amide-Gln-N. A fifth aliquot did not contain any labelled $\mathrm{N}$ compound and was used to determine the natural abundance of ${ }^{15} \mathrm{~N}$. However, due to a technical limitation of the ${ }^{15} \mathrm{~N}$ IRMS analysis, a subset of germinants had to be grown on medium with a lower fraction of isotopic label for day 6 and 24 of germination (1\% ${ }^{15} \mathrm{~N}$ of respective $\mathrm{N}$ source). Due to insufficient amount of sample for day 1 and a shortage of mature somatic embryos for experimental use, day 1 and 12 were omitted from the IRMS analysis. The germination of somatic embryos was observed and documented before sampling using a digital camera (D5000, Nikon).

Samples were collected after 1, 3, 6, 12 and 24 days of germination. The experiment required approximately 4500 mature somatic embryos in total. Hence, to make the start-up

Table $1 \mathrm{~N}$ composition of the germination medium

\begin{tabular}{lccll}
\hline & $\mathrm{mM} \mathrm{N}$ & $\mathrm{mg} \mathrm{N} \mathrm{L}$ & mg N plate & \% of total $N$ \\
\hline $\mathrm{NH}_{4}{ }^{+}$ & 2.1 & 29.9 & 0.7 & 12 \\
$\mathrm{NO}_{3}{ }^{-}$ & 9.7 & 135.7 & 3.4 & 54 \\
$\mathrm{Gln}$ & 6.2 & 86.2 & 2.2 & 34 \\
Total & 18.0 & 251.8 & 6.3 & \\
\hline
\end{tabular}


and sampling manageable, the work of placing the somatic embryos on the germination media was carried out over a number of days. At each sampling, all germinated somatic embryos were counted in each Petri dish, pooled into one biological replicate and weighed (fresh weight; FW). The somatic seedlings collected at 24 days were cut at the shoot-root junction and the shoots and roots were collected separately. Unless stated differently, five biological replicates were analysed for each treatment and at each of the five time points. All samples were frozen in liquid $\mathrm{N}_{2}$ and freeze-dried for $72 \mathrm{~h}$ (Scanvac Coolsafe freeze dryer, LaboGeneTM, Denmark). Sample DW was measured and the samples were ground for 3 min using a bead mill (MM400, Retsch GmbH, Germany) set to a frequency of $25 \mathrm{~Hz} \mathrm{~s}^{-1}$, with three $3 \mathrm{~mm}$ tungsten beads.

\section{Analysis of tissue $\mathrm{C}, \mathrm{N}$ and ${ }^{15} \mathrm{~N}$}

The tissue concentrations of $\mathrm{C}$ and $\mathrm{N}$ (w/w; presented as $\mathrm{C} \%$ or $\mathrm{N} \%$ ) of the germinants grown on the unlabelled germination medium, was determined using an elemental analyser (Flash EA 2000, Thermo Fisher Scientific, Bremen, Germany). The ${ }^{15} \mathrm{~N}$ content of the germinants, grown on ${ }^{15} \mathrm{~N}$-labelled germination media, was determined using an isotope ratio mass spectrometer (IRMS; DeltaV, Thermo Fisher Scientific, Bremen, Germany) interfaced to the element analyser (Flash EA 2000). Sample weight used for elemental analysis was $2 \mathrm{mg}( \pm 10 \%) \mathrm{DW}$.

\section{Analysis of AA concentrations}

Two mg of freeze-dried sample was extracted in $0.01 \mathrm{M}$ $\mathrm{HCl}$ and $\mathrm{AA}$ concentrations were measured according to the UPLC-AccQTag method (UPLC amino acid analysis system solution, http://www.waters.com).

\section{Targeted AA analysis}

The targeted AA analysis [original technique described by Gullberg et al. (2004)] was performed as described in Carlsson et al. (2017) with the following changes; (1) the internal standard (norvaline) was maintained at $0.5 \mathrm{pmol}$ on the column for the calibration curve and (2) a $1 \mu \mathrm{L}$ aliquot of the sample was injected for the LC-MS analysis. The LC-MS analysis was controlled by the MassHunter ${ }^{\mathrm{TM}}$ software package, v B.05.01 and data processing was performed using the MassHunter ${ }^{\mathrm{TM}}$ Profinder software, v B.08.00 (Agilent Technologies Inc., Santa Clara, CA, USA). The concentration of $\mathrm{N}\left(\mu \mathrm{mol} \mathrm{g}{ }^{-1} \mathrm{DW}\right)$ assimilated from the ${ }^{15} \mathrm{~N}$-labelled germination media into AAs in the TFAA pool was calculated according to Carlsson et al. (2017).

\section{Calculations and statistical analysis}

All calculations of means and standard error of mean (SEM) were performed using the Microsoft Excel software (Microsoft Corporation, USA). Statistical differences were tested by ANOVA analysis and Tukey HSD test using JMP Pro software (SAS Institute Inc, USA), a $P$ value of $<0.05$ was defined as statistically significant.

\section{Results}

\section{Somatic embryo biomass changes during germination}

The average biomass (FW and DW, and the FW/DW ratio) of a germinating embryo at the different time points is shown in Table 2. Germinant fresh biomass increased significantly throughout the sampling series, from $1.6 \pm 0.03 \mathrm{mg}$ at day 1 to $13.2 \pm 0.24 \mathrm{mg}$ at day 24 . Germinant dry biomass did not increase significantly between day $1(0.49 \pm 0.01 \mathrm{mg})$ and day $3(0.52 \pm 0.01 \mathrm{mg})$, whereas at day 6 , the dry biomass had almost doubled $(0.99 \pm 0.02 \mathrm{mg})$. Between day 6 and 24 the germinants increased their dry biomass further, with a final biomass of $1.69( \pm 0.03) \mathrm{mg}$ at day 24 , 3.4 -fold more than the starting weight. FW/DW ratio was $3.2 \pm 0.08$ at day 1 and thereafter it increased to $4.8 \pm 0.17$ at day $3,7.5 \pm 0.19$ at day 6 and reached $9.0 \pm 0.08$ at day 12 , then the ratio declined to $8.0 \pm 0.06$ at day 24 .

\section{Germinant $\mathrm{C}$ and $\mathrm{N}$ status}

Germinant $\mathrm{C}$ concentration decreased significantly between day 1,3 and 5, from $57 \%$ at day 1 to $45 \%$ at day 12 and remained unchanged between day 12 and 24 (Fig. 1a). Germinant $\mathrm{N}$ concentration did not change significantly over days 1 to 6 at 4.9-5.0\%, whereas at day 12 and 24 a significant increase to $5.7 \%$ and $5.8 \%$ respectively was recorded (Fig. 1b). To examine the cumulative content of $\mathrm{C}$ and $\mathrm{N}$ taken up from the medium, a statistical analysis was carried out, comparing the $\mathrm{C}$ and $\mathrm{N}$ content in the germinating embryos versus the initial value obtained from the desiccated embryos before placing them on germination medium (Table S1, average for all batches). $\mathrm{C}$ content during germination followed a similar pattern to that of DW biomass development, being unchanged for the first three days in comparison with the starting $\mathrm{C}$ content, followed by a significant increase of $88 \%$ at day 6 (Fig. 1c). The $\mathrm{C}$ content was then unchanged between day 6 and 12, whereas between day 12 and 24, the $\mathrm{C}$ content was significantly increased by an additional $120 \%$. Taken together, the $\mathrm{C}$ content in the somatic embryos increased by 3.1 -fold during the germination experiment compared with the $\mathrm{C}$ content of a somatic 
Table 2 Biomass (i.e. FW, DW and FW/DW ratio) of the somatic embryos at day 1, 3, 6, 12 and 24 of germination (mg per somatic embryo \pm SEM; $n \geq 49$ )

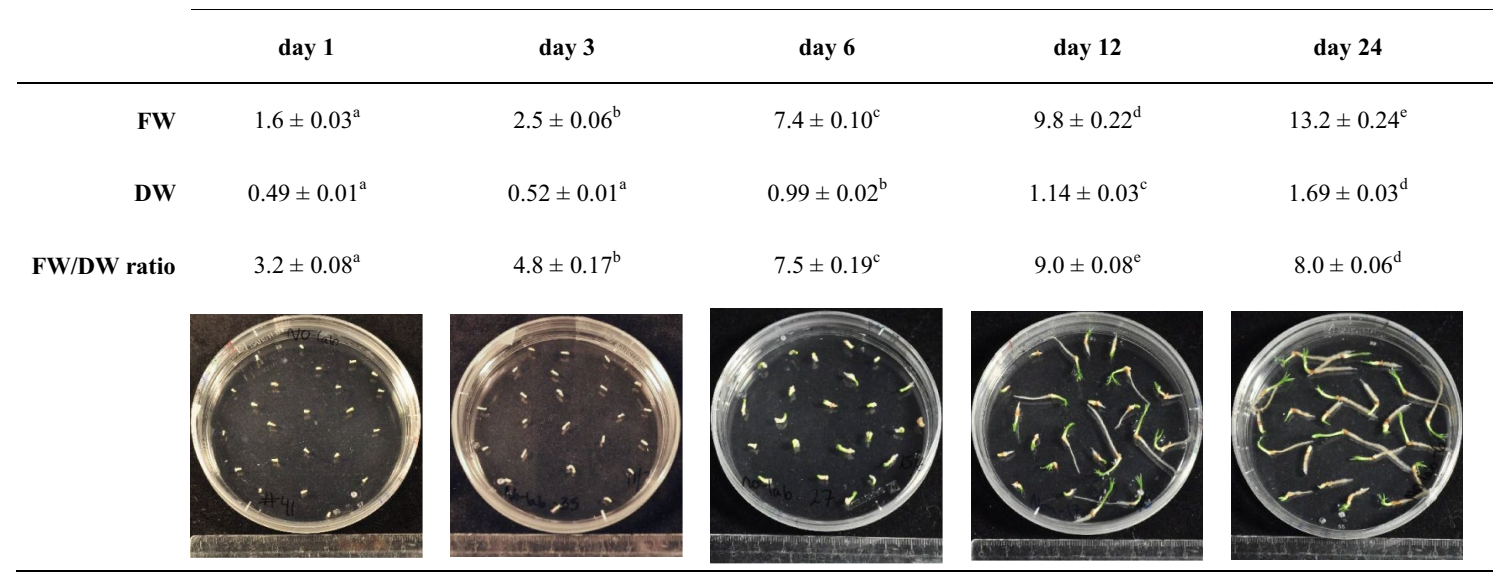

Different letters indicate significant differences among means $(P<0.05)$

embryo. Similarly, the N content did not increase significantly in comparison with the starting $\mathrm{N}$ content during the first 3 days. At day 6, the $\mathrm{N}$ content had increased significantly by $76 \%$ and continued to rise, increasing 3.6 -fold over the 24-day germination (Fig. 1d).

\section{$\mathrm{N}$ uptake in germinating embryos}

To investigate $\mathrm{N}$ uptake, a reciprocal ${ }^{15} \mathrm{~N}$-labelling experiment was conducted, whereby ${ }^{15} \mathrm{~N}$ provided by the different $\mathrm{N}$ sources in the growth medium and absorbed by the embryo, was analysed using EA-IRMS. The total N concentration in the medium was $18 \mathrm{mM}$, with individual $\mathrm{N}$ sources corresponding to $9.7 \mathrm{mM} \mathrm{NO}_{3}{ }^{-}-\mathrm{N}, 2.1 \mathrm{mM}$ $\mathrm{NH}_{4}{ }^{+}-\mathrm{N}$ and $6.2 \mathrm{mM}$ Gln-N (Table 1). Since 23 embryos were placed on $25 \mathrm{ml}$ of medium, each somatic embryo had access to $273.7 \mu \mathrm{g} \mathrm{N}$, consisting of $147.5 \mu \mathrm{g} \mathrm{NO}{ }_{3}^{-}-\mathrm{N}$, $32.5 \mu \mathrm{g} \mathrm{NH}_{4}{ }^{+}-\mathrm{N}$ and $93.7 \mu \mathrm{g}$ Gln-N, representing 54\%, $12 \%$ and $34 \%$ of total $\mathrm{N}$ (Table 3 ). After 3 days of germination, each germinant contained on average $28.9 \mu \mathrm{g} \mathrm{N}$, of which $27 \%$ originated from the medium. The respective $\mathrm{N}$ sources $\left(\mathrm{NO}_{3}{ }^{-}-\mathrm{N}, \mathrm{NH}_{4}{ }^{+}-\mathrm{N}\right.$ and Gln-N) contributed to $2.3 \pm 0.4$, $1.9 \pm 0.4$ and $3.7 \pm 0.7 \mu \mathrm{g} \mathrm{N}$ per embryo, corresponding to $29 \%, 24 \%$ and $47 \%$ of the total $\mathrm{N}$ taken up. After 6 days, $52 \%$ of the total $\mathrm{N}$ in the germinant originated from the medium, corresponding to $2.7 \pm 0.5 \mu \mathrm{g} \mathrm{NO}_{3}{ }^{-}-\mathrm{N}, 2.8 \pm 0.6 \mu \mathrm{g}$ $\mathrm{NH}_{4}{ }^{+}-\mathrm{N}$ and $6.8 \pm 1.4 \mu \mathrm{g}$ Gln-N. The fractions of $\mathrm{NO}_{3}{ }^{-}-\mathrm{N}$, $\mathrm{NH}_{4}{ }^{+}-\mathrm{N}$ and Gln-N contribution were $22 \%, 23 \%$ and $55 \%$ of total $\mathrm{N}$ taken up. At day 24 of germination, the $\mathrm{N}$ content in an average germinant was $110.5 \mu \mathrm{g} \mathrm{N}$, of which $90 \%$ was taken up from the medium. The contribution of the three $\mathrm{N}$ sources was $30 \pm 6.5 \mu \mathrm{g} \mathrm{NO}{ }_{3}^{-}-\mathrm{N}, 19.5 \pm 3.6 \mu \mathrm{g} \mathrm{NH}_{4}{ }^{+}-\mathrm{N}$ and $50.5 \pm 9.4 \mu \mathrm{g}$ Gln-N, representing $30 \%, 19 \%$ and $51 \%$ of total $\mathrm{N}$ taken up.

\section{$\mathrm{N}$ assimilation into the TFAA pool}

To further investigate the $\mathrm{N}$ metabolism in germinating somatic embryos we also assessed the TFAA pool and its composition. The TFAA pool concentration increased significantly throughout the germination phase, from $118 \pm 10 \mu \mathrm{mol} \mathrm{g}^{-1} \mathrm{DW}$ at day 1 to $1172 \pm 72 \mu \mathrm{mol} \mathrm{g}^{-1} \mathrm{DW}$ at day 24, an almost 10-fold increase (Fig. 2a). With respect to the TFAA profiles at the different time points, Gln and Arg were the only AAs at a concentration higher than 5\% of TFAA at all five measured time points (Fig. 2b). Gln was the overall most abundant AA, ranging from $33 \%$ at day 1 to $69 \%$ at day 24 of the TFAA pool, followed by Arg that fluctuated from $29 \%$ at day 1 to $16 \%$ at day 3 , to $12 \%$ at day 6 , to $14 \%$ at day 12 and reached $17 \%$ at day 24 of the TFAA pool. In addition, the asparagine (Asn) concentration was higher than 5\% of the TFAA pool at all time points except day at 3 . The sum fraction of AAs with an individual concentration lower than $5 \%$ of the TFAA pool decreased from $25 \%$ at day 1 to only $5 \%$ at day 24 .

\section{Assimilation of the $\mathrm{N}$ sources}

Targeted AA profiling using ${ }^{15} \mathrm{~N}$-labelled $\mathrm{N}$ sources was carried out to assess the relative contribution of each $\mathrm{N}$ source to $\mathrm{N}$ metabolism, i.e. to what extent each $\mathrm{N}$ source taken up was assimilated into AAs. For the results presented in this section, Gln is separated from the remaining TFAA pool. The reasons for separating Gln from the other AAs when analysing $\mathrm{N}$ assimilation are: (1) When ${ }^{15} \mathrm{Gln}$ is included in the media, it is not possible to distinguish between taken up, non-metabolised ${ }^{15} \mathrm{~N}$-Gln present in the germinants and ${ }^{15} \mathrm{~N}$ Gln generated from internal metabolism (even though the $\mathrm{N}$ is derived from Gln supplied in the medium). (2) The tissue concentration of Gln in the germinants was high, accounting 
(a) 60

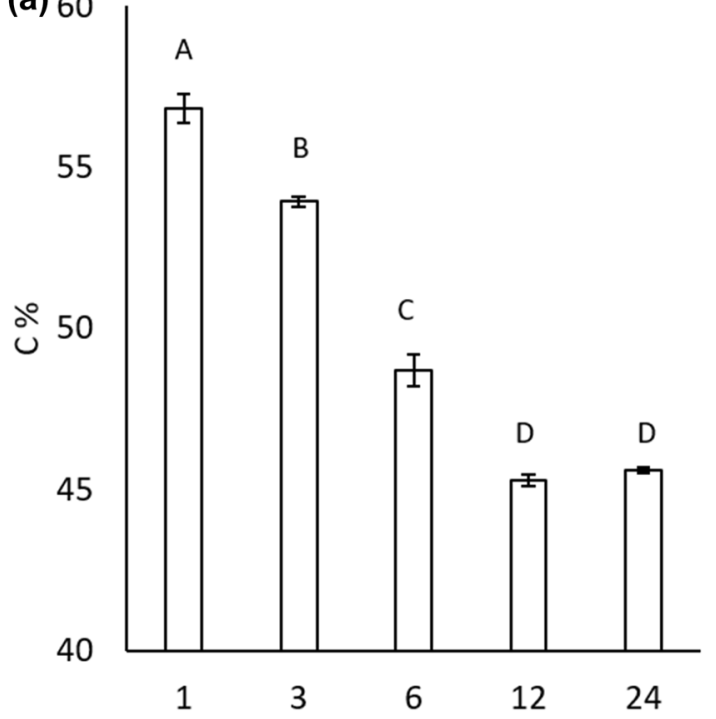

(c)

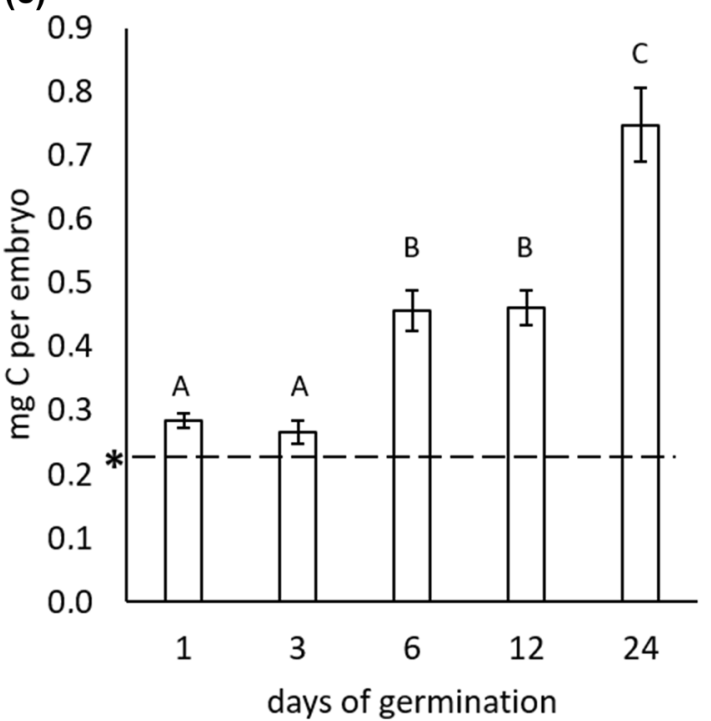

Fig. $1 \mathrm{C}$ and $\mathrm{N}$ concentration and content in the somatic embryos at day 1, 3, 6, 12 and 24 of germination. $\mathrm{C} \%$ (a) and $\mathrm{N} \%$ (b) $(\mathrm{w} / \mathrm{w} \pm \mathrm{SEM}) . \mathrm{C}$ content $(\mathbf{c})$ and $\mathrm{N}$ content (d) during the germination period of 24 days (mg per embryo \pm SEM; $n=5$ ). Different let-

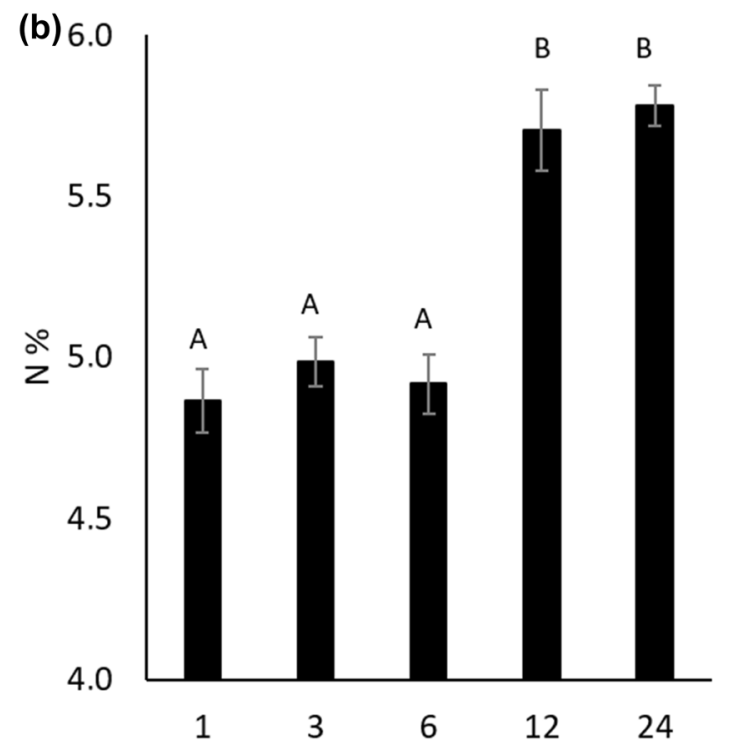

(d)

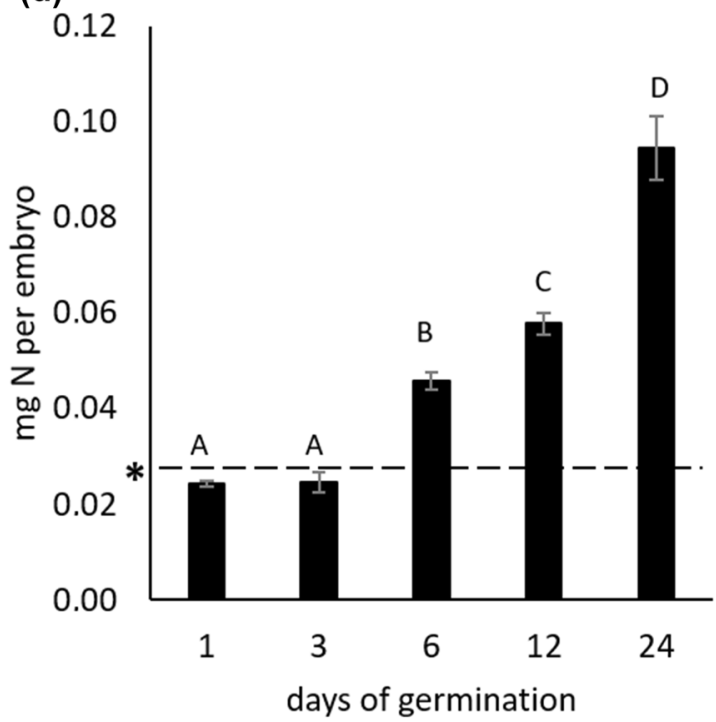

ters indicate significant differences among means $(P<0.05)$. *Indicate starting $\mathrm{C}$ and $\mathrm{N}$ content of a desiccated mature somatic embryo before placing it on the germination medium

tion of $\mathrm{N}$ taken up as $\mathrm{NO}_{3}{ }^{-}, \mathrm{NH}_{4}{ }^{+}$or Gln per somatic embryo at day 3,6 and 24 of germination ( $\mu \mathrm{g} \mathrm{N}$ per somatic embryo $\pm \mathrm{SEM} ; n=5$ )
Table 3 Amount and percental composition of available $\mathrm{N}$ in the form of $\mathrm{NO}_{3}{ }^{-}, \mathrm{NH}_{4}{ }^{+}$and Gln added in the germination medium per somatic embryo (first column to the left) and the amount and propor-

Day $6 \quad$ Day 24

$\mu \mathrm{g} \mathrm{N}$ per somatic embryo

$\begin{array}{lll}2.3 \pm 0.4(29 \%) & 2.7 \pm 0.5(22 \%) & 30.0 \pm 6.5(30 \%) \\ 1.9 \pm 0.4(24 \%) & 2.8 \pm 0.6(23 \%) & 19.5 \pm 3.6(19 \%) \\ 3.7 \pm 0.7(47 \%) & 6.8 \pm 1.4(55 \%) & 50.5 \pm 9.4(51 \%)\end{array}$


for up to $69 \%$ of the TFAA pool. Hence, by presenting the incorporation of $\mathrm{N}$ into Gln separately, a wider data interpretation was possible. Moreover, no major differences in the incorporation of Gln amide $\mathrm{N}$ and amine $\mathrm{N}$ into the TFAA pool were observed, therefore the sum of amide and amine $\mathrm{N}$ is presented as Gln-N hereafter.

The contribution of each $\mathrm{N}$ source assimilated into the TFAA pool (except Gln) is shown in Table 4. The corresponding data showing the incorporation of the different
$\mathrm{N}$ sources into Gln is shown in Table 5. The relative contribution of the different $\mathrm{N}$ sources to the TFAA pool was relatively stable during the germination period (Table 4), with $\mathrm{NO}_{3}{ }^{-}-\mathrm{N}, \mathrm{NH}_{4}{ }^{+}-\mathrm{N}$ and Gln- $\mathrm{N}$ representing on average 22,25 and $53 \%$ of the assimilated $\mathrm{N}$, respectively.

The fractions of $\mathrm{N}$ derived from the three different $\mathrm{N}$ sources found in Gln (Table 5) followed a similar pattern to that of the TFAA pool (Gln excluded; Table 4). The only difference was a slightly higher fraction of $\mathrm{NH}_{4}{ }^{+}-\mathrm{N}$ assimilated

(a)

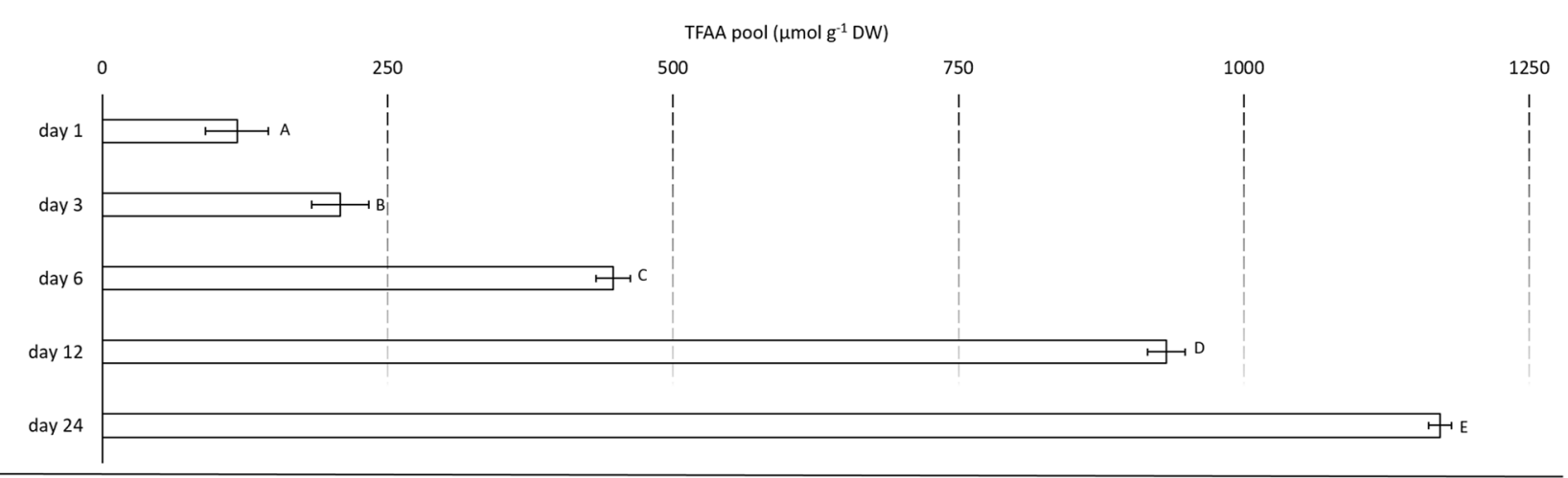

(b)

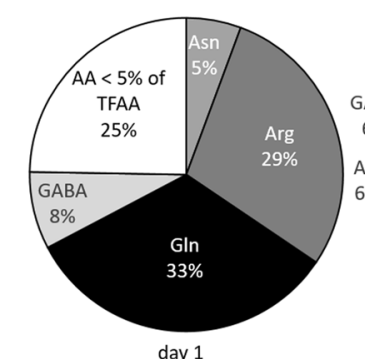

day 1

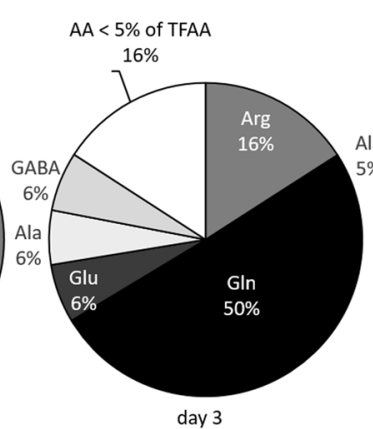

day 3
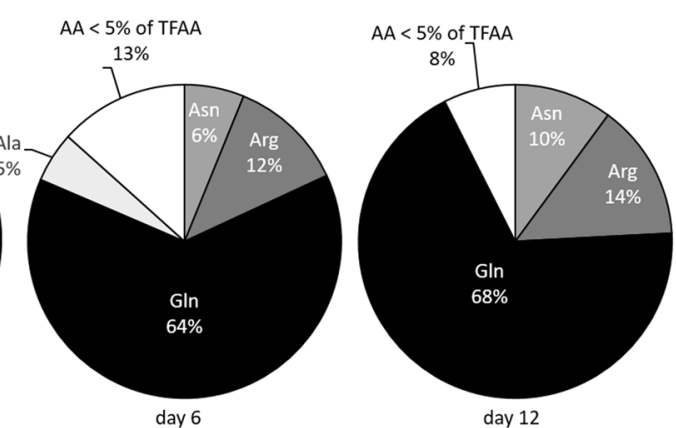

AA $<5 \%$ of TFAA

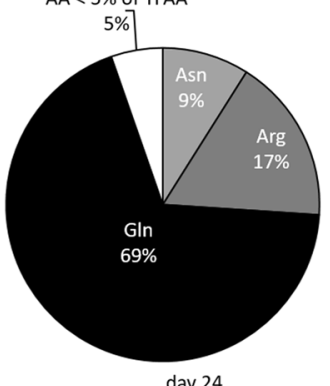

Fig. 2 The TFAA pool concentration (a) and profile (b) in Norway spruce somatic embryos at day 1, 3, 6, 12 and 24 of germination ( $\mu$ mol g ${ }^{-1}$ $\mathrm{DW} \pm \mathrm{SEM} ; n=25)$. Different letters indicate significant differences among means $(P<0.05)$

Table 4 Concentration and percentage of $\mathrm{N}$ from each $\mathrm{N}$ source, $\mathrm{NO}_{3}{ }^{-}, \mathrm{NH}_{4}{ }^{+}$or Gln, assimilated into the TFAA pool (excluding any N assimilated into Gln) in somatic embryos at day $1,3,6,12$ and 24 of germination $\left(\mu \mathrm{mol} \mathrm{N} \mathrm{g}{ }^{-1} \mathrm{DW} \pm \mathrm{SEM} ; n=5\right)$

\begin{tabular}{lrrrrr}
\hline & $\begin{array}{l}\text { Day } 1 \\
\mu \text { mol N g }\end{array}$ & Day 3 & Day 6 & Day 12 & Day 24 \\
\hline $\mathrm{NO}_{3}{ }^{-}$ & $3.4 \pm 0.5(24 \%)$ & $10.9 \pm 1.2(22 \%)$ & $27 \pm 2(24 \%)$ & $70 \pm 3(22 \%)$ & $111 \pm 7(20 \%)$ \\
$\mathrm{NH}_{4}{ }^{+}$ & $3.4 \pm 0.6(23 \%)$ & $11.1 \pm 0.7(23 \%)$ & $28 \pm 3(25 \%)$ & $81 \pm 5(25 \%)$ & $148 \pm 10(27 \%)$ \\
$\mathrm{Gln}$ & $7.9 \pm 1.8(54 \%)$ & $26.3 \pm 3.7(55 \%)$ & $56 \pm 5(50 \%)$ & $176 \pm 13(53 \%)$ & $281 \pm 17(53 \%)$ \\
\hline
\end{tabular}

Table 5 Concentration and percentage of $\mathrm{N}$ from each $\mathrm{N}$ source, $\mathrm{NO}_{3}{ }^{-}, \mathrm{NH}_{4}{ }^{+}$or Gln, found in or assimilated into Gln in somatic embryos at day 1 , $3,6,12$ and 24 of germination $\left(\mu \mathrm{mol} \mathrm{N} \mathrm{g}{ }^{-1} \mathrm{DW} \pm \mathrm{SEM} ; n=5\right)$

\begin{tabular}{|c|c|c|c|c|c|}
\hline & $\begin{array}{l}\text { Day } 1 \\
\mu \mathrm{mol} \mathrm{Ng}^{-1} \mathrm{DW}\end{array}$ & Day 3 & Day 6 & Day 12 & Day 24 \\
\hline $\mathrm{NO}_{3}^{-}$ & $3.3 \pm 0.3(26 \%)$ & $9.5 \pm 0.8(22 \%)$ & $30 \pm 5(24 \%)$ & $74 \pm 9(21 \%)$ & $143 \pm 17(20 \%)$ \\
\hline $\mathrm{NH}_{4}^{+}$ & $3.3 \pm 0.6(27 \%)$ & $12.1 \pm 1.0(27 \%)$ & $41 \pm 5(32 \%)$ & $113 \pm 9(32 \%)$ & $190 \pm 5(27 \%)$ \\
\hline Gln & $5.9 \pm 1.6(47 \%)$ & $22.5 \pm 3.3(51 \%)$ & $56 \pm 4(44 \%)$ & $162 \pm 18(46 \%)$ & $368 \pm 13(52 \%)$ \\
\hline
\end{tabular}


into Gln between days 1-12 (27-32\% for Gln as compared with $23-25 \%$ for the TFAA pool) and a corresponding a lower Gln-N fraction in Gln during day 1 to day 12. However, at day 24 , the $\mathrm{N}$ source patterns of the TFAA pool and Gln were similar. When analysing the incorporation of ${ }^{15} \mathrm{~N}$ into individual amino acids, we found that Arg was far more ${ }^{15} \mathrm{~N}$-enriched than all other AAs except Gln (Table S3). The interpretation of ${ }^{15} \mathrm{~N}$ incorporation into Gln is more complex due to the reasons already mentioned. However, in terms of $\mathrm{NO}_{3}{ }^{-}$and $\mathrm{NH}_{4}{ }^{+}$derived $\mathrm{N}$, approximately $50 \%$ more $\mathrm{N}$ was assimilated into Gln than into Arg.

\section{Discussion}

This work aimed at increasing our understanding of Norway spruce somatic embryo germination, by assessing the importance of $\mathrm{C}$ and $\mathrm{N}$ supplied in the medium, with the focus on the relative contribution of the provided $\mathrm{N}$ sources. To investigate this, mature somatic embryos were monitored for biomass changes, $\mathrm{C}$ - and $\mathrm{N}$ budget, and $\mathrm{N}$ assimilation over the first 24 days of germination in low-intensity red light. We found, as expected, that $\mathrm{C}$ and $\mathrm{N}$ supplied in the medium was of great importance, as illustrated by the germinants 3.1 to 3.6-fold increase in these elements over the 24-day germination period. With respect to $\mathrm{N}$ source and $\mathrm{N}$ assimilation, Gln accounted for $50 \%$ or more of total N, supporting the proposed hypothesis that it was the preferred source of $\mathrm{N}$. $\mathrm{NO}_{3}{ }^{-}$on the other hand, being the most abundant medium $\mathrm{N}$ source was the least utilized.

\section{Biomass changes, $\mathrm{C}$ and $\mathrm{N}$ uptake during the first 24 days of germination}

For the first 3 days of germination no major differences were observed in the analysed parameters. At this point, the germinant was probably re-hydrating (Table 2; FW/DW ratio) and initializing metabolic pathways involved in germination. At day 6 , the $\mathrm{C}$ concentration had decreased from $57 \%$ to $49 \%$ (Fig. 1a) and at the same time the total $\mathrm{C}$ content had increased by $88 \%$ (Fig. 1c). This suggested that (1) stored $\mathrm{C}$ was metabolised and (2) $\mathrm{C}$ was taken up from the medium. The results thus suggest that a substantial part of the $\mathrm{C}$ stored in the germinants is in the form of lipids, since the germinants had a relatively high $\mathrm{C}$ concentration. In an earlier study, lipids bodies have also been found in somatic embryos and were considered as an indicator of a viable embryo (Carrier et al. 1997). Between day 6 and 12, the $\mathrm{C}$ content remained unchanged whereas the $\mathrm{C}$ concentration continued to decrease, suggesting that lipid reserves transformed into other C-compounds with a relatively higher oxygen content. Alternatively, the lipids may also have been respired and the $\mathrm{C}$ content was maintained by the uptake of sucrose $\mathrm{C}$. The unchanged $\mathrm{C}$ content could be due to several factors. Around day 6-12 many morphological changes occurred; the germinants developed into seedling-like structures with a pronounced root and shoot and at the same time it can be assumed that cell-expansion also took place. These processes are likely associated with respiration costs, something that could explain the unchanged $\mathrm{C}$ content. Finally, between day 12-24, C concentration did not change, and C content increased by an additional $120 \%$, suggesting that the storage lipids were consumed, and that medium supplied sucrose was the driving factor for growth during that time-frame.

The increase of germinant $\mathrm{N}$ content followed closely the same pattern as that of $\mathrm{C}$, with the exception that $\mathrm{N}$ content increased consistently after day 6 , without stagnating at day 12 . After 3 days, $27 \%$ of the total $\mathrm{N}$ content in the germinating somatic embryos originated from the medium, which increased to $52 \%$ and $90 \%$ on days 6 and 24 respectively. It is therefore clear that the somatic germinants were highly dependent on medium supplied $\mathrm{N}$ for their growth. With respect to the uptake preference, we found that somatic germinants appeared to prefer Gln, followed by $\mathrm{NH}_{4}{ }^{+}$and $\mathrm{NO}_{3}{ }^{-}$. Gln-N accounted for at least $50 \%$ of total $\mathrm{N}$ uptake, consistent with previous findings on $\mathrm{N}$ uptake in PEMs of Norway spruce (Carlsson et al. 2017). However, even though conifers have been found to take up AAs in quantities comparable to $\mathrm{NH}_{4}{ }^{+}$and $\mathrm{NO}_{3}{ }^{-}$(Metcalfe et al. 2011; Gruffman et al. 2013, 2014), most plant literature addresses mineral $\mathrm{N}$ and the preference for either $\mathrm{NH}_{4}{ }^{+}$or $\mathrm{NO}_{3}{ }^{-}$. Hence, the ecological relevance of plant AA uptake is under debate, but these results challenge this dogma, at least in terms of plant in vitro culture. Excluding Gln, the results presented here suggest that the somatic germinants preferred $\mathrm{NH}_{4}{ }^{+}$, corroborating previous reports that conifer species have an uptake preference for $\mathrm{NH}_{4}{ }^{+}$as compared with $\mathrm{NO}_{3}{ }^{-}$(Öhlund and Näsholm 2001; Miller and Hawkins 2007).

\section{$\mathrm{N}$ assimilation into the TFAA pool}

In this study, ${ }^{15} \mathrm{~N}$-labelled $\mathrm{NO}_{3}{ }^{-}-\mathrm{N}, \mathrm{NH}_{4}{ }^{+}-\mathrm{N}$ and Gln-N was traced into primary $\mathrm{N}$ assimilation (TFAAs) during the first 24 days of Norway spruce somatic embryo germination. After 3 days on germination medium, $\mathrm{N}$ originating from all $\mathrm{N}$ sources occurred in all AAs analysed. Gln and the inorganic $\mathrm{N}$ sources contributed approximately equally to assimilated $\mathrm{N}$ found in the TFAA pool (Table 4), indicating that the Gln supplied in the medium was a significant source of $\mathrm{N}$ for somatic embryo $\mathrm{N}$ metabolism during germination. However, the relative amount of inorganic $\mathrm{N}$ assimilated into TFAA did not reflect the amount of $\mathrm{N}$ taken up from the medium, i.e. $\mathrm{NO}_{3}{ }^{-}-\mathrm{N}$ accounted for $30 \%$ of the total $\mathrm{N}$ uptake at day 24 of germination (Table 3), whereas $\mathrm{NO}_{3}{ }^{-}-\mathrm{N}$ accounted for only $20 \%$ of the TFAA pool 
at day 24 (Table 4). A possible explanation for this difference is that a part of the $\mathrm{NO}_{3}{ }^{-}$taken up is not assimilated into TFAA but instead is stored as $\mathrm{NO}_{3}{ }^{-}$, presumably in vacuoles (Andrews et al. 2013). Moreover, as $\mathrm{NO}_{3}{ }^{-}$and $\mathrm{NO}_{2}{ }^{-}$reduction enzymes are light regulated (Kaiser et al. 2002; Krapp 2015) and $\mathrm{NO}_{3}{ }^{-}$assimilation is partly dependent on photosynthesis through ferredoxin (Joy and Hageman 1966; Hanke et al. 2004), the utilization of $\mathrm{NO}_{3}{ }^{-}$may have been negatively affected by the non-photosynthetic lighting conditions used in this study. The assimilation of $\mathrm{NO}_{3}{ }^{-}$can also be repressed when the concentration of Gln is high as, for example, in fungi, due to a process called 'nitrogen metabolite repression' (Crawford and Arst 1993; Gent and Forde 2017). Contrary to $\mathrm{NO}_{3}{ }^{-}, \mathrm{NH}_{4}{ }^{+}$was found to account for a larger fraction of assimilated $\mathrm{N}$ as compared with its contribution to total $\mathrm{N}$ uptake, i.e. $27 \%$ of the TFAA pool $\mathrm{N}$ at day 24 (Table 4) versus $19 \%$ of total $\mathrm{N}$ uptake at day 24 (Table 3), suggesting that $\mathrm{NH}_{4}{ }^{+}$assimilation was less restricted than that of $\mathrm{NO}_{3}{ }^{-}$. Furthermore, the TFAA pool increase during germination also demonstrates an active $\mathrm{N}$ metabolism, synthesising new AAs that could be used for protein production and subsequently for the growth, which in turn suggests no apparent limitation of metabolism/assimilation via the GS/GOGAT pathway.

\section{Utilization of exogenously added $\mathbf{N}$}

The high uptake and assimilation of Gln suggest that it is a preferred $\mathrm{N}$ source for germination, the question is why? In Carlsson et al. (2017) it was evident that SE cell culture was relying on medium supplied with Gln as a $\mathrm{N}$ donor to make large amounts of Ala. In this study however, high tissue levels of Ala were not present. Perhaps the most logical explanation in the context of somatic embryo germination is that $\mathrm{NO}_{3}{ }^{-}$was a non-preferential $\mathrm{N}$-source as opposed to Gln being a preferred one and the relatively low utilization of $\mathrm{NO}_{3}{ }^{-}$would force the germinants to search for other sources of $\mathrm{N}$. Moreover, compared with mineral $\mathrm{N}$ that must be assimilated in a process that requires energy (Bloom et al. 1992; Zerihun et al. 1998), Gln is an already assimilated N source and it therefore saves energy and C (Franklin et al. 2017). The germination medium used for the experiments was, in addition to $3.1 \mathrm{mM}$ Gln, also supplied with $\mathrm{NH}_{4}{ }^{+}$ and $\mathrm{NO}_{3}{ }^{-}$at a ratio of 0.22 with respect to $\mathrm{N}$, a composition that has been found to be optimal for the initiation and maintenance of Norway spruce SE culture (Bozhkov et al. 1993). Even though it was developed for initiation and SE culture, this $\mathrm{N}$ composition is also suitable for germination. Compared with other plant media, e.g. Murashige and Skoog (1962), with a $\mathrm{NH}_{4}{ }^{+}$to $\mathrm{NO}_{3}{ }^{-}$ratio of 0.5 , the relative amount of $\mathrm{NH}_{4}{ }^{+}$in the germination medium is low. As the utilization of $\mathrm{NO}_{3}{ }^{-}$was limited, it could suggest that it would be beneficial to increase the fraction of $\mathrm{NH}_{4}{ }^{+}$in the germination media. However, the rationale for using a low concentration of $\mathrm{NH}_{4}{ }^{+}$is to minimise the risk of $\mathrm{NH}_{4}{ }^{+}$ toxicity and avoid acidification of the culture media caused by the $\mathrm{NH}_{4}{ }^{+}$uptake (Kaul and Hoffman 1993). It is thus not certain that $\mathrm{NH}_{4}{ }^{+}$at a higher concentration in the germination medium would improve $\mathrm{N}$ utilization.

\section{AA metabolism during germination}

In this study, the germinants were placed in a N-rich environment, possibly leading to excessive $\mathrm{N}$ uptake. Given the substantial assimilation of $\mathrm{NO}_{3}{ }^{-}$and $\mathrm{NH}_{4}{ }^{+} \mathrm{N}$ into Gln and other AAs, our data did not suggest that uptake and assimilation of mineral $\mathrm{N}$ were highly inhibited despite a high internal concentration of tissue $\mathrm{N}$, resulting in a build-up of the N-rich AAs Gln and Arg (Fig. 2b). Hence, the $\mathrm{N}$ in the cells of germinating Norway spruce somatic embryos could be incorporated into the AAs GIn and Arg as a way of storing it, similarly to what has been reported for maturing seeds of other conifer species (King and Gifford 1997; reviewed by; Cánovas et al. 2007). This is also in agreement with the studies on seed germination of white spruce (Gifford and Tolley 1989) and loblolly pine (Pinus taeda) (King and Gifford 1997), which showed that hydrolyzation and mobilization of storage reserves cause a concentration increase in the TFAA pool, with Glu, Gln and Arg being the most abundant (King and Gifford 1997). The accumulation of AAs with a possible function in $\mathrm{N}$ storage presented in this work, might explain why red light treatment had a positive impact on the somatic embryo development and overall germination success in Norway spruce (Kvaalen and Appelgren 1999) and pine species (Merkle et al. 2005). However, further studies of this process under white light are required to confirm this hypothesis.

\section{Summary}

This study showed that $\mathrm{C}$ and $\mathrm{N}$ stored during the maturation phase was not sufficient for the somatic embryo during germination, thus making it dependent on the accessible resources in the medium. The utilization of different $\mathrm{N}$ sources, together with $\mathrm{N}$ available in the medium, suggested that the uptake was controlled, preferring Gln and $\mathrm{NH}_{4}{ }^{+}$over $\mathrm{NO}_{3}{ }^{-}$. The finding that Gin-N accounted for $50 \%$ or more of $\mathrm{N}$ taken up and assimilated is new considering that the majority of the relevant publications have focused on $\mathrm{NH}_{4}{ }^{+}$ and $\mathrm{NO}_{3}{ }^{-}$utilization. The results presented here justify Gln and perhaps also other forms of organic $\mathrm{N}$ to be regarded as major sources of $\mathrm{N}$ in the context of plant in vitro culture. However, to validate this claim, experiments on additional plant species are required. The low uptake and assimilation of $\mathrm{NO}_{3}{ }^{-}$could also imply that the fraction of $\mathrm{NO}_{3}{ }^{-}$in 
the medium was higher than necessary. On the other hand, this study was only covering half the germination time and theoretically, at the end of the second germination phase $\mathrm{N}$ or specific $\mathrm{N}$ source depletion is possible. This suggests that there are factors in the somatic embryo germination process to investigate further, e.g. the uptake and assimilation of different $\mathrm{N}$ sources under white light, a knowledge needed to balance the medium composition with the requirements of germinating somatic embryos.

Author contribution statement Conceptualization: JC, HS, UG. Data curation: JC, HS. Formal analysis: JC, HS. Funding acquisition: HS, UE. Investigation: JC, HS. Project administration: HS, UG. Supervision: HS, UG, UE. Validation: JC, HS, UG. Visualization: JC, HS. Writing - original draft: JC, HS, UG. Writing - review and editing: JC, HS, UE, UG.

Acknowledgements This study was conducted within the 2nd Research School of Forest Genetics, Biotechnology and Breeding (http://ressc hool.slu.se/), Umeå Plant Science Centre (UPSC) and Swedish University of Agricultural Sciences (SLU) Sweden, in collaboration with Svenska Skogsplantor AB (http://www.skogsplantor.se/). The work was financed by Svenska Skogsplantor AB, the Swedish Governmental Agency for Innovation Systems (VINNOVA; UPSC Berzelii Center for Forest Biotechnology 2012-01560; www2.vinnova.se; including support to U.E), H.S (Nils and Dorthi Troedsson foundation; 859/15; http://www.troedssonfonden.se). The authors declare that they have no conflict of interest. Swedish Metabolomics Centre, Umeå, Sweden (http://www.swedishmetabolomicscentre.se) is acknowledged for the ${ }^{15} \mathrm{~N}$-incorporation measurements by LCMS.

\section{Compliance with ethical standards}

Conflict of interest The authors declare that they have no conflict of interest.

Open Access This article is distributed under the terms of the Creative Commons Attribution 4.0 International License (http://creativeco mmons.org/licenses/by/4.0/), which permits unrestricted use, distribution, and reproduction in any medium, provided you give appropriate credit to the original author(s) and the source, provide a link to the Creative Commons license, and indicate if changes were made.

\section{References}

Alvarez J, Bueno N, Cortizo M, Ordás R (2013) Improving plantlet yield in Pinus pinaster somatic embryogenesis. Scand J For Res 28:613-620. https://doi.org/10.1080/02827581.2013.821516

Andrews M, Raven JA, Lea PJ (2013) Do plants need nitrate? The mechanisms by which nitrogen form affects plants. Ann Appl Biol 163:174-199. https://doi.org/10.1111/aab.12045

Barrett JD, Park YS, Bonga JM (1997) The effectiveness of various nitrogen sources in white spruce [Picea glauca (Moench) Voss] somatic embryogenesis. Plant Cell Rep 16:411-415
Bloom AJ, Sukrapanna SS, Warner RL (1992) Root respiration Associated with ammonium and nitrate absorption and assimilation by barley. Plant Physiol 99:1294-1301

Bozhkov P, von Arnold S (1998) Polyethylene glycol promotes maturation but inhibits further development of Picea abies somatic embryos. Physiol Plantarum 104:211-224

Bozhkov PV, Mikhlina SB, Shiryaeva GA, Lebedenko LA (1993) Influence of nitrogen balance of culture medium on Norway spruce [Picea abies (L.) Karst] somatic polyembryogenesis: high frequency establishment of embryonal-suspensor mass lines from mature zygotic embryos. J Plant Physiol 142:735-741

Canales J, Bautista R, Label P et al (2014) De novo assembly of maritime pine transcriptome: implications for forest breeding and biotechnology. Plant Biotechnol J 12:286-299

Cánovas F, Avila C, Cantón F, Cañas R, de la Torre F (2007) Ammonium assimilation and amino acid metabolism in conifers. J Exp Bot 58:2307-2318

Carlsson J, Svennerstam H, Moritz T, Egertsdotter U, Ganeteg U (2017) Nitrogen uptake and assimilation in proliferating embryogenic cultures of Norway spruce-investigating the specific role of glutamine. PLoS ONE 12(8):e0181785. https://doi. org/10.1371/journal.pone.0181785

Carneros E, Toribio M, Celestino C (2017) Effect of ABA, the auxin antagonist PCIB and partial desiccation on stone pine somatic embryo maturation. Plant Cell Tiss Organ Cult 131:445-458

Carrier DJ, Cunningham JE, Taylor DC, Dunstan DI (1997) Sucrose requirements and lipid utilization during germination of interior spruce (Picea glauca engelmannii complex) somatic embryos. Plant Cell Rep 16:550-554

Ching TM (1966) Compositional changes of Douglas fir seeds during germination. Plant Physiol 41:1313-1319

Crawford N, Arst H (1993) The molecular genetics of nitrate assimilation in fungi and plants. Annu Rev Genet 27:115-146

Dobrowolska I, Businge E, Abreu I, Moritz T, Egertsdotter U (2017) Metabolome and transcriptome profiling reveal new insights into somatic embryo germination in Norway spruce (Picea abies). Tree Physiol 37:1752-1766. https://doi.org/10.1093/ treephys/tpx078

Egertsdotter U, Clapham D (2011) Method for maturing and synchronizing conifer somatic embryos. Patent Pub. No.: US 2013/0065306 A1

Elhiti M, Stasolla C, Wang A (2013) Molecular regulation of plant somatic embryogenesis. In Vitro Cell Dev Biol Plant 49:631-642

Forde BG, Lea PJ (2007) Glutamate in plants: metabolism, regulation, and signalling. J Exp Bot 58:2339-2358

Franklin O, Cambui CA, Gruffman L, Palmroth S, Oren R, Näsholm T (2017) The carbon bonus of organic nitrogen enhances nitrogen use efficiency of plants. Plant Cell Environ 40(1):25-35. https:// doi.org/10.1111/pce. 12772

Gent L, Forde B (2017) How do plants sense their nitrogen status? J Exp Bot 68:2531-2540. https://doi.org/10.1093/jxb/erx013

George E, de Klerk G-J (2008) The components of plant tissue culture media I: macro- and micro-nutrients. In: George E, Hall M, de Klerk G-J (eds) Plant propagation by tissue culture, vol 1, 3rd edn. The background. Springer, Dordrecht, pp 65-113

Gifford D, Tolley M (1989) The seed proteins of white spruce and their mobilization following germination. Physiol Plantarum 77:254-261

Goldberg R, de Paiva G, Yadegari R (1994) Plant embryogenesis: Zygote to seed. Science 266:605-614

Gruffman L, Palmroth S, Näsholm T (2013) Organic nitrogen uptake of Scots pine seedlings is independent of current carbohydrate supply. Tree Physiol 33:590-600

Gruffman L, Jämtgård S, Näsholm T (2014) Plant nitrogen status and co-occurrence of organic and inorganic nitrogen sources influence root uptake by Scots pine seedlings. Tree Physiol 34:205-213 
Gullberg J, Jonsson P, Nordström A, Sjöström M, Moritz T (2004) Design of experiments: an efficient strategy to identify factors influencing extraction and derivatization of Arabidopsis thaliana samples in metabolomic studies with gas chromatography/mass spectrometry. Anal Biochem 331:283-295

Hakman I (1993) Embryology in Norway spruce (Picea abies). An analysis of the composition of seed storage proteins and deposition of storage reserves during seed development and somatic embryogenesis. Physiol Plantarum 87:148-159

Hamasaki R, Purgatto E, Mercier H (2005) Glutamine enhances competence for organogenesis in pineapple leaves cultivated in vitro. Braz J Plant Physiol 17:383-389

Hanke GT, Kimata-Ariga Y, Taniguchi I, Hase T (2004) A post genomic characterization of arabidopsis ferredoxins. Plant Physiol 134:255-264. https://doi.org/10.1104/pp.103.032755

Hazubska-Przybył T, Wawrzyniak M (2017) Stimulation of somatic embryo growth and development in Picea spp. by polyethylene glycol. Dendrobiology 78:168-178

Hazubska-Przybył T, Wawrzyniak M, Obarska A, Bojarczuk K (2015) Effect of partial drying and desiccation on somatic seedling quality in Norway and Serbian spruce. Acta Physiol Plant 37:1735. https://doi.org/10.1007/s11738-014-1735-1

Hristoforoglu K, Schmidt J, Bolhar-Nordenkampf H (1995) Development and germination of Abies alba somatic embryos. Plant Cell Tiss Org 40:277-284

Huppe HC, Turpin DH (1994) Integration of carbon and nitrogen metabolism in plant and algal cells. Annu Rev Plant Physiol Plant Mol Biol 45:577-607

Joy KW, Hageman RH (1966) The purification and properties of nitrite reductase from higher plants, and its dependence on ferredoxin. Biochem J 100:263-273

Kaiser W, Weiner H, Kandlbinder A, Tsai C-B, Rockel P, Sonoda M, Planchet E (2002) Modulation of nitrate reductase: some new insights, an unusual case and a potentially important side reaction. J Exp Bot 53:875-882

Kaul K, Hoffman SA (1993) Ammonium ion inhibition of Pinus strobus L. callus growth. Plant Sci 88(2):169-173

Khlifi S, Tremblay F (1995) Maturation of black spruce somatic embryos. Part I. Effect of L-glutamine on the number and germinability of somatic embryos. Plant Cell Tiss Org 41:23-32

King J, Gifford D (1997) Amino acid utilization in seeds of loblolly pine during germination and early seedling growth (I. Arginine and Arginase Activity). Plant Physiol 113:1125-1135. https://doi. org/10.1104/pp.113.4.1125

Kirby E (1982) The effects of organic nitrogen sources on growth of cell cultures of Douglas-fir. Physiol Plantarum 56:114-117

Klimaszewska K, Bernier-Cardou M, Cyr DR, Sutton BCS (2000) Influence of gelling agents on culture medium gel strength, water availability, tissue water potential, and maturation response in embryogenic cultures of Pinus strobus L. Vitro Cell Dev Biol Plant 36:279-286

Klimaszewska K, Morency F, Jones-Overton C, Cooke J (2004) Accumulation pattern and identification of seed storage proteins in zygotic embryos of Pinus strobus and in somatic embryos from different maturation treatments. Physiol Plant 121:682-690

Klimaszewska K, Hargreaves C, Lelu-Walter MA, Trontin JF (2016) Advances in conifer somatic embryogenesis since year 2000. In: Germanà MA, Lambardi M (eds) In vitro embryogenesis in higher plants. Humana Press, Hatfield, pp 131-166

Klubicová K, Uvácková L, Danchenko M, Nemecek P, Skultéty L, Salaj J, Salaj T (2017) Insights into the early stage of Pinus nigra Arn. somatic embryogenesis using discovery proteomics. J Proteom 169:99-111. https://doi.org/10.1016/j.jprot.2017.05.013

Krapp A (2015) Plant nitrogen assimilation and its regulation: a complex puzzle with missing pieces. Curr Opin Plant Biol 25:115-122
Krasavina M, Burmistrova N, Raldugina G (2014) The role of carbohydrates in plant resistance to abiotic stresses. In: Ahmad P, Rasool $\mathrm{S}$ (eds) Emerging technologies and management of crop stress tolerance, vol 1. Elsevier Inc, San Diego, pp 229-270

Krogstrup P (1986) Embryo-like structures from cotyledons and ripe embryos of Norway spruce (Picea abies). Can J Forest Res 16:664-668

Kvaalen H, Appelgren M (1999) Light quality influences germination, root growth and hypocotyle elongation in somatic embryos but not in seedlings of Norway spruce. In Vitro Cell Dev Biol Plant 35:437-441

Lam HM, Coschigano K, Oliveira IC, Melo-Oliveira R, Coruzzi G (1996) The molecular-genetics of nitrogen assimilation into amino acids in higher plants. Annu Rev Plant Physiol Plant Mol Biol 47:569-593

Lammer D, Gifford D (1989) Lodgepole pine seed germination. II. The seed proteins and their mobilization in the megagametophyte and embryonic axis. Can J Bot 67:2544-2551

Lea PJ, Ireland RJ (1999) Nitrogen Metabolism in Higher Plants. In: Singh B (ed) Plant amino acids: biochemistry and biotechnology. Marcel Dekker Inc, New York, pp 1-47

Lelu-Walter M-A, Gautier F, Eliášová K et al (2018) High gellan gum concentration and secondary somatic embryogenesis: two key factors to improve somatic embryo development in Pseudotsuga menziesii [Mirb.]. Plant Cell Tiss Organ Cult 132:137-155. https://doi.org/10.1007/s11240-017-1318-0

Llebrés M-T, Avila C, Cánovas F, Klimaszewska K (2017) Root growth of somatic plants of hybrid Pinus strobus (L.). and $P$. wallichiana (A. B. Jacks.) is affected by the nitrogen composition of the somatic embryo germination medium. Trees. https ://doi.org/10.1007/s00468-017-1635-2

Merkle S, Montello P, Xia X, Upchurch B, Smith D (2005) Light quality treatments enhance somatic seedling production in three southern pine species. Tree Physiol 26:187-194

Metcalfe RJ, Nault J, Hawkins BJ (2011) Adaptations to nitrogen form: comparing inorganic nitrogen and amino acid availability and uptake by four temperate forest plants. Can J Forest Res 41:1626-1637

Miller BD, Hawkins BJ (2007) Ammonium and nitrate uptake, nitrogen productivity and biomass allocation in interior spruce families with contrasting growth rates and mineral nutrient preconditioning. Tree Physiol 27:901-909

Montalbán IA, De Diego N, Moncaleán P (2010) Bottlenecks in Pinus radiata somatic embryogenesis: improving maturation and germination. Trees 24:1061-1071

Morel A, Teyssier C, Trontin J-F et al (2014a) Early molecular events involved in Pinus pinaster Ait. somatic embryo development under reduced water availability: transcriptomic and proteomic analyses. Physiol Plant 152:184-201. https://doi.org/10.1111/ ppl.12158

Morel A, Trontin J-F, Corbineau F et al (2014b) Cotyledonary somatic embryos of Pinus pinaster Ait. most closely resemble fresh, maturing cotyledonary zygotic embryos: biological, carbohydrate and proteomic analyses. Planta 240:1075-1095. https ://doi.org/10.1007/s0042

Murashige T, Skoog F (1962) A Revised Medium for Rapid Growth and Bio Assays with Tobacco Tissue Cultures. Physiol Plantarum 15:473-497

Nunes-Nesi A, Fernie A, Stitt M (2010) Metabolic and Signaling Aspects Underpinning the Regulation of Plant Carbon Nitrogen Interactions. Mol Plant 3:973-996

Ogita S, Sasamoto H, Yeung E, Thorpe T (2001) The effects of glutamine on the maintenance of embryogenic cultures of Cryptomeria japonica. Vitro Cell Dev Biol Plant 37:268-273

Öhlund J, Näsholm T (2001) Growth of conifer seedlings on organic and inorganic nitrogen sources. Tree Physiol 21:1319-1326 
Pinto A, Byrne D, Dethier Rogers S (1993) Influence of ovule perforation, plant growth regulators, and l-glutamine on in vitro growth of immature peach embryos. Vitro Cell Dev Biol Plant 29:55-58

Pratelli R, Pilot G (2014) Regulation of amino acid metabolic enzymes and transporters in plants. J Exp Bot 65(19):5535-5556

Pullman G, Bucalo K (2014) Pine somatic embryogenesis: analyses of seed tissue and medium to improve protocol development. New Forest 45:353-377

Pullman G, Zeng X, Copeland-Kamp B, Crockett J, Lucrezi J, May S, Bucalo K (2015) Conifer somatic embryogenesis: improvements by supplementation of medium with oxidation-reduction agents. Tree Physiol 35:209-224. https://doi.org/10.1093/treephys/tpu117

Robinson AR, Dauwe R, Ukrainetz NK, Cullis IF, White R, Mansfield SD (2009) Predicting the regenerative capacity of conifer somatic embryogenic cultures by metabolomics. Plant Biotechnol J 7:952-963. https://doi.org/10.1111/j.1467-7652.2009.00456.x

Stasolla C, Belmonte M, Van Zyl L, Craig D, Liu W, Yeung E, Sederoff $\mathrm{R}$ (2004) The effect of reduced glutathione on morphology and gene expression of white spruce (Picea glauca) somatic embryos. J Exp Bot 55:695-709

Stitt M (1999) Nitrate regulation of metabolism and growth. Curr Opin Plant Biol 2:178-186

Stone S, Gifford D (1997) Structural and biochemical changes in loblolly pine (Pinus taeda L.) seeds during germination and early-seedling growth. i. storage protein reserves. Int J Plant Sci 158:727-737

Trontin J-F, Klimaszewska K, Morel A, Hargreaves C, Lelu-Walter M-A (2016) Molecular aspects of conifer zygotic and somatic embryo development: a review of genome-wide approaches and recent insights. In: Germanà MA, Lambardi $M$ (eds) In vitro embryogenesis in higher plants. Humana Press, Hatfield, pp 167-208

Vasudevan A, Selvaraj N, Ganapathi A, Kasthurirengan S, Ramesh Anbazhagan V, Manickavasagam M (2004) Glutamine: a suitable nitrogen source for enhanced shoot multiplication in Cucumis sativus L. Biol Plantarum 48:125-128

Winkelmann T (2016) Somatic versus zygotic embryogenesis: learning from seeds. In: Germanà MA, Lambardi M (eds) In vitro embryogenesis in higher plants. Humana Press, Hatfield, pp 25-46

Yaseen M, Ahmad T, Sablok G, Standardi A, Ahmad Hafiz I (2012) Review: role of carbon sources for in vitro plant growth and development. Mol Biol Rep 40:2837-2849

Zerihun A, McKenzie BA, Morton JD (1998) Photosynthate costs associated with the utilization of different nitrogen-forms: influence on the carbon balance of plants and shoot-root biomass partitioning. New Phytol 138:1-11 